\title{
SURVIVAL PROBLEMS OF THE WATER-PIPIT IN BAFFIN ISLAND
}

\author{
George Miksch Sutton* and David F. Parmelee ${ }^{\dagger}$
}

TN Rougher parts of southern Baffin Island the Water-Pipit (Anthus spinoletta) breeds regularly in considerable numbers. In 1877-8 Kumlien (1879, p. 74) found it "generally distributed on both sides of Cumberland Sound and the west shores of Davis Straits to lat. $68^{\circ} \mathrm{N}$. at least, but nowhere very abundant." Soper (1928, p. 115) reported it as "common everywhere about Cumberland Sound" (summer of 1924); "very scarce" in the region of Isoa "during June and most of July" but "much more common toward the last of July" (1925); and "quite common"-at Cape Dorset from June 1 on in the summer of 1926. Taverner $(1935$, p. 128) called it "common" in southern Baffin Island. Dalgety (1936, p. 582) found it the commonest bird near Ravenscraig Harbour, in Eglinton Fiord, from 14 to 29 August 1934. Shortt and Peters (1942, p. 347) considered it "The most abundant land bird of the high rocky coastal region about Hudson Strait", and reported it from Arctic Bay, Pond Inlet, and Pangnirtung. Bray (1943, pp. 532-3) observed it north to Fury and Hecla Strait, and evidently believed that it bred even farther north, in the part of Baffin Island known as Cockburn Land. Bent (1950, p. 35) included Arctic Bay and Pond Inlet in the breeding range, presumably on the authority of Shortt and Peters (1942). Wynne-Edwards (1952, p. 379) found it the third commonest bird at the head of Clyde Inlet in the summer of 1950-only the Lapland Longspur (Calcarius lapponicus) and the Snow Bunting (Plectrophenax nivalis) being more abundant.

Some of these authors, notably Soper, Dalgety, and Wynne-Edwards, discuss the pipit's seasonal fluctuations, and point out that in certain areas throughout which it does not breed it is sometimes common as a transient; none of them discusses fluctuations from year to year, however, and none expresses an opinion as to whether it is becoming more common or extending its range. Kumlien $(1879$, p. 73$)$ is the only one who reports destruction of adults on a grand scale. He writes: "During the first of June we had the severest snow-storm of the season, and I think most of them perished. They would come around the observatory and shelter themselves as best they could. They were so far reduced that they were easily caught with the hand." Wynne-Edwards (1952, p. 379) reports the loss of a nest with six eggs (possibly robbed by a weasel or fox) and of one egg from another clutch of six. Pickwell (1947, pp. 7-12), discussing a nest with six young found by him on July 17 at 6,500 feet elevation near Frozen Lake, on the northeast side of Mount

*Professor of Zoology and Curator of Birds, University of Oklahoma.

+Graduate Assistant, Department of Zoology, University of Oklahoma. 
Rainier in the State of Washington, reports, but makes no attempt to explain, the death of two of the brood and the disappearance of two others within the following 12 days.

In the vicinity of the Royal Canadian Air Force station near the head of Frobisher Bay, Baffin Island, the Water-Pipit was the third commonest bird from 14 June to 22 August 1953. The Snow Bunting and Lapland Longspur were more common, the Horned Lark (Eremopbila alpestris) almost as common. In a broad sense these four species occupied the same areas, but their numbers varied according to habitat, the bunting preferring rocks, the longspur grassy tundra, the lark gravel flats, and the pipit moss-grown slopes with southern exposure.

The pipit was less common at the airfield than on the rocky slopes just to the east and north, but we found one nest in the wide expanse of flat land near the airfield, and another in flat land just west of the mouth of the Jordan River. This was a surprise, for several authors had called attention to the species' avoidance of flat country in the nesting season (Sutton, 1932, p. 225; Soper, 1946, p. 420; and Wynne-Edwards, 1952, p. 379).

The pipit was the only species of the above-mentioned four to suffer really heavy losses of any sort during the summer of 1953. We found one adult dead near a road leading from the airfield to the bay shore (July 29); eleven nestlings (two nests) were destroyed by predators, and twenty-one welldeveloped young birds were found dead in nests (see Table 1). The latter had obviously not been bitten, chewed, or mauled; nor had they, as far as we could tell, been killed by nest parasites or disease. They must have died of starvation or exposure, or both, and the starvation almost certainly resulted from the inability of the parent birds to find sufficient insect food. Bad weather in July so immobilized the insects or cut down their rate of development that they were exceedingly hard to find. We, who were observing all this, considered ourselves fortunate in being able, day after day, to cross miles of tundra afoot without being bothered by mosquitoes. But the very factors which kept the mosquitoes down created a serious insect shortage for the birds, especially the pipit. We emphasize this because virtually all the young birds we found dead in nests were pipits.

The pipit's favourite slopes were comparatively free of wind in rough weather, and warm when the sun was out. On windy, bright days butterflies, crane-flies, and spiders were apt to be commoner here than elsewhere. The pipit's nest was likely to be found under the shaggy protection of the arctic heather, Cassiope tetragona, tucked away at the head of a little ravine or beside a big rock.

By foot we covered fairly often and regularly an 18-square-mile area north and east of the airfield. In the monotonous, plateau-like interior we did not encounter the pipit very often; but along the larger streams, and where the rocky land sloped abruptly down to salt water, the species was sure to be found. Several pairs nested along the nearer bank of the Sylvia Grinnell River, just west of the airfield. On the cliff-like western side of Hill Island, across the bay southwest of the airfield, several pairs nested. Near the mouth 


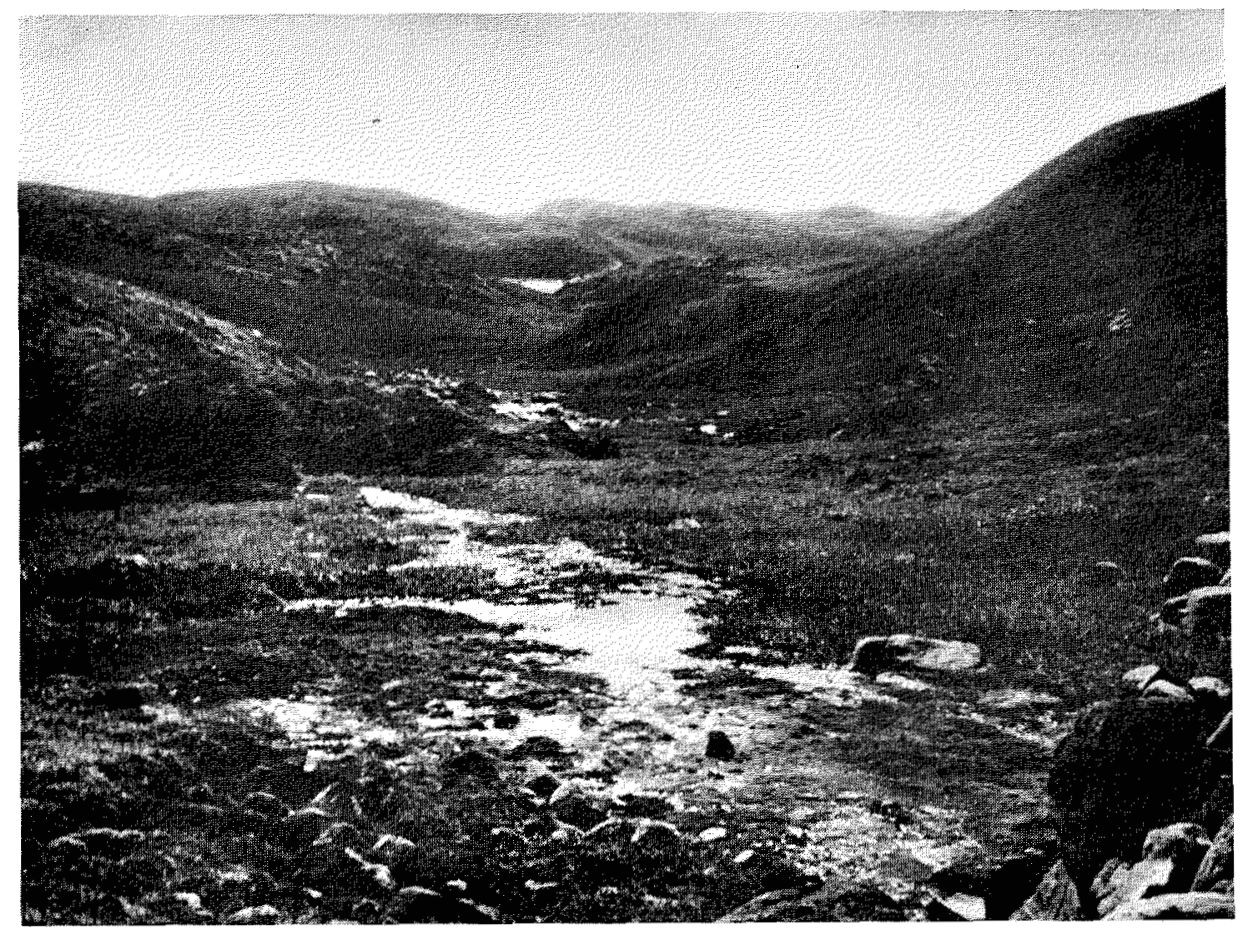

Fig. 1. Typical Water-Pipit nesting habitat just north of Tarr Inlet, near the head of Frobisher Bay, 28 July 1953.

of the Jordan River, sixteen miles away, we saw many pipits on July 13 and from July 17 to 20 . In the vicinity of a large lake at $68^{\circ} 31 \mathrm{~N} ., 71^{\circ} 22 \mathrm{~W}$, about fifty miles east-northeast of Wordie Bay, we saw a few pipits, both adult and young, on August 8. Our seeing the species at all the above-named places made the more noticeable our failure to find it at $65^{\circ} 20 \mathrm{~N}$., $77^{\circ} 10 \mathrm{~W}$., near Cape Dorchester, on August 11, and along the southeastern shore of Amadjuak Lake at $64^{\circ} 38 \mathrm{~N}$., $70^{\circ} 28 \mathrm{~W}$, , on August 8 and 15. These two areas are largely flat. Soper (1946, p. 420) thus describes this part of Baffin Island: "From the swampy tundras of the west, relieved by no outcropping granites, the birds are entirely absent, except for a few scattered individuals that resort to beach lines during migration."

\section{Behaviour}

When we started our work at the airfield on June 15, we saw and heard pipits wherever we went. Most individuals that we looked at closely were a beautiful pinkish buff below, ashy gray above, and not very heavily streaked on the chest and sides. Since several of these sparsely streaked birds were singing, we assumed that all such birds were males and that the heavily streaked birds were females. In this we were quite wrong, as sexing of collected specimens showed. We saw no flocks: the birds were paired. We failed to find a nest or to see a bird carrying nest material. 
On June 17 there was much flight-singing along the sheltered slopes north and east of the airfield, but most of the flight-songs seemed to be brief, perhaps because of the wind. On June 21 (minimum temperature $30.9^{\circ} \mathrm{F}$, maximum $44.8^{\circ} \mathrm{F}$, prevailing wind NNW., 16 m.p.h.) we observed several pipits singing flight-songs. The songs were a simple repetition of a chwee or cburee note, but toward the middle of the series a slight change in tempo or enunciation gave the performance two distinct parts. As the notes continued, the singer continued to climb, usually rather gradually, sometimes steeply, then down he came with tail closed and lifted and wings partly spread to lessen the rapidity of descent. Singing sometimes started before the bird left the ground and continued after he had alighted (Murie in Bent, 1950, p. 33; Pickwell, 1947 , p. 6), but such prolongation of the performance was exceptional.

On June 22 we found our first pipit nest (for details see pp. 87-8) while scouring the area in hope of finding the nest of a Harlequin Duck (Histrionicus bistrionicus), a species we failed to record, though it had been reported from Baffin Island (Soper, 1928, p. 88; 1946, pp. 21-2). The pipit flew out with an explosive flutter of wings, hovered above the water a few feet away, and called tsi-tsi excitedly. When it alighted it did not feign injury. Its mate did not appear.

On June 24 , in high country about a mile northeast of the airfield, we followed a pair of pipits about for some time, wondering if they had a nest. They were obviously much disturbed by our presence. Finally we collected the duller, more heavily streaked bird (GMS 11723), and found that it had a well-defined brood-patch. This bird's call-note had been tsi-tsi. The other bird, whose underparts were of a strongly pinkish shade, returned several times to the spot at which it had last seen its mate, calling weet sharply and performing brief flight-songs. We collected this bird (GMS 11722), and found that it had no brood-patch. The much-streaked bird proved to be a female, the other a male. In both specimens the gonads were much enlarged.

At 6 a.m. on June 25, after a full hour of observation, we found Nest 2. We first saw a pair of pipits quietly feeding along the lower edge of a big snowbank, and guessed that they were not far from their nest. The birds started walking down the slope together, the brighter in the lead. Presently this bird, which we believe to have been the male, flew northward about a hundred yards, alighting in plain sight. The female now gave several sharp $t s i$-tsi alarm notes. The male answered with a loud, far-carrying weet, not unlike one of the familiar alarm cries of the Wheatear (Oenanthe oenonthe). The female was obviously ill at ease, and finally approached the male with fluttering wings and loud cries which resembled those of a begging nestling. We had been watching the male, so knew that he had been looking for food; but we supposed he had been eating all he had found. It now became apparent that he had gathered a considerable mouthful, for he fed the female, even picking up and giving to her bits which fell to the ground. Between about 4 a.m. and $5.55 \mathrm{a} . \mathrm{m}$. she flew to her mate for food fourteen times. After her fourteenth trip, her behaviour changed. She stood high for an instant just after alighting, looked about, then lowered her head and walked directly to 
the nest. Her every activity had been, most of this time, within a few yards of the nest except when she flew to the male to be fed. Before each feeding her $t s i$-tsi cries accelerated until they ran together in a continuous sound of begging. When the female flushed she fluttered downslope, touching the ground occasionally as she flew.

On June 30 we came upon a brood of young only a few days out of the nest. We found the young birds while moving cautiously along the edge of a small rock-rimmed lake stalking a male Old-squaw (Clangula byemalis). The several fledglings sprang up all at once and, though noticeably stub-tailed, flew fairly well. This brood was probably at least 15 days old. Hatching having taken place not later than June 15 , and the incubation period having been at least 12 days (Pickwell, 1947, p. 12), the last egg of the clutch must have been laid about June $3-$ a very much earlier date than that on which we found our first nest. On consulting the meteorologists at the airfield, we learned that there had been an unusually mild spell in late May and early June, a period spring-like enough, obviously, to have led some pairs of pipits to proceed with nesting. This was the only brood which we know to have been reared wholly during June, but our several observations of nest-failure in mid-July led us to wonder whether the 1953 crop of young pipits might have been largely of June broods. In this connection it is interesting that Wheeler (in Austin, 1932, p. 175) saw "young able to fly short distances" on June 16 in the Kiglapait Mountains, in Labrador; that Wynne-Edwards (1952, p. 379) found a nest with six eggs at the head of Clyde Inlet on June 13; and that there are, in the Colorado Museum of Natural History, eggs collected along the Chipp River, on the Arctic Slope of Alaska, as early as May 27 (Bailey, 1948, p. 286).

In all, we found fourteen nests between June 22 and July 18. Observations at these nests and information gained through collecting specimens, convinced us that the male pipit does not incubate. Austin (1932, p. 175) states that "incubation is performed by both sexes", but none of the three adult males we collected (respectively on June 24, 26, and 29) had the slightest indication of a brood-patch; the one adult female we collected had a well-defined broodpatch; and each of the four incubating birds we caught at the nest and banded had a well defined brood-patch but no indication of a coiled vas deferens in the region of the anus. Furthermore, repeated observation convinced us that birds which approached their mates with fluttering wings and begging cries were females; that birds which gave a double alarm note ( $t$ si-tsi or $c h i-c b i$ ) near the nest were females; and that birds which gave a weet alarm note at the nest were males. We never observed an incubating female receiving food from her mate at the nest proper. We found Nest 7 (see below) by watching a male, with mouth full of food, alight near the nest; the female left the nest, approached her mate with fluttering wings, and received the food.

Our latest date for a full flight-song was July 13, near the mouth of the Jordan River. V. C. Wynne-Edwards told us of hearing a brief song some miles east of the airfield on July 23. On August 1 we noted several adults in moulting condition, one of them stub-tailed. 


\section{Incubation period}

The incubation period at one nest (Nest 2), which we visited frequently, was shown to be at least 11 days, 23 hours, and 15 minutes (6 a.m. on June 25 to 5.15 a.m. on July 7), and almost certainly longer, since when we found the nest the clutch was complete. Pickwell $(1947$, p. 12) found the incubation period to be "a full twelve days". According to "The handbook of British birds' (1948, Vol. 1, p. 205), the incubation period of Anthus s. spinoletta of the Old World is "about 14 days".

At one nest (Nest 7), four eggs hatched within a 24-hour period. At another nest (Nest 8), a five-egg clutch hatched within at least 16 hours, at most 25 hours and 30 minutes. Size-variation in the brood of six found in Nest 10 clearly indicated that hatching had not been simultaneous and that incubation had begun well before the clutch was complete.

\section{Fledging period}

The fledging period in Baffin Island was at least 12 days, at most 14 days (Nest 3). Johnson (1933, pp. 114-5) reports a fledging period of at least 13 days. Wynne-Edwards (1952, p. 379) calls attention to the possibility that young pipits normally leave the nest before they can fly.

\section{Nest observations}

All of the fourteen nests found were lined solely with grass; in none was there a feather, tuft of bog-cotton, or plant-down of any sort. Moss was included in the foundation material, but in general the walls and bottoms were of grass. All the nests were more or less hidden under vegetation, principally Cassiope tetragona, but none was in a crevice among rocks in the sort of site preferred by the Snow Bunting. Soper (1946, p. 420) describes a pipit nest having such a site.

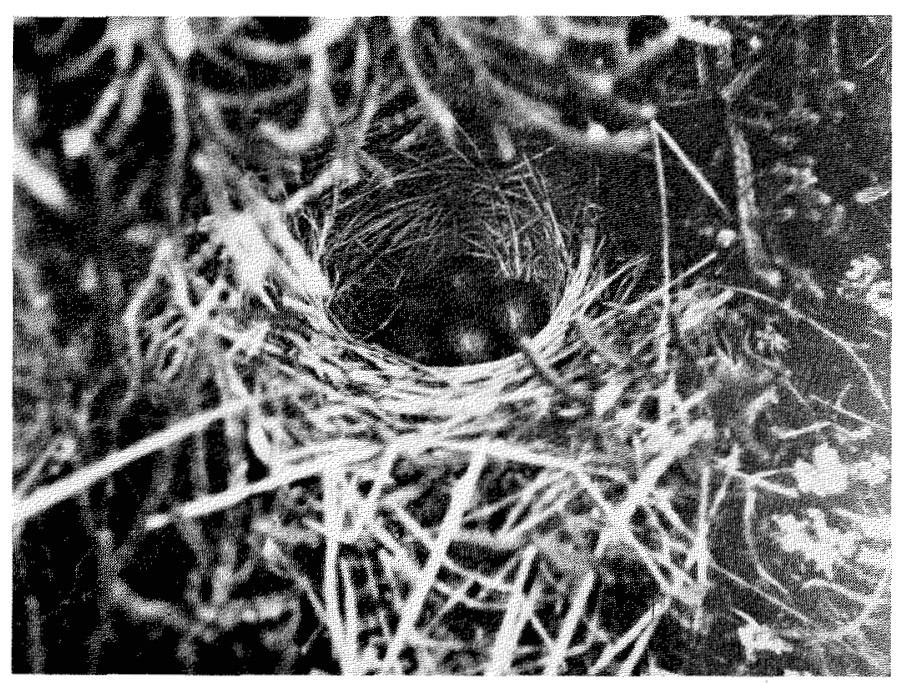

Fig. 2. Nest and eggs of Water-Pipit, near the head of Frobisher Bay, 4 July 1953. 
Clutch-size varied. Two nests held three eggs each, but we were not sure that either of these clutches was complete. Three nests held six eggs each. Nine nests held five eggs each. Of the seventy-nine eggs known by us to have been laid, at least five did not hatch. Of the fifty-seven young which we know or believe did hatch, only three were known by us to have fledged successfully; twelve may possibly have fledged, for the nests held particles of feather-sheaths; ten may or may not have fledged (we saw them only once); eleven were destroyed, while still in the nest by predators; and twenty-one died in the nest from starvation or exposure (or both) when almost fledged.

The following notes give brief details on nesting sites and observations at the nest. Our data on hatching success of the fourteen nests is summarized in Table 1.

Nest 1. Found June 22 in Cassiope on a bank overhanging a swift stream near the Hudson's Bay Company's post: 6 eggs. June 25, 6 eggs; July 22, one egg and feather-sheath particles, so the brood may have fledged.

Nest 2. Found June 25 on a high, southward-facing sheltered slope, half a mile northeast of the airfield: 5 eggs. June 27,5 eggs; July 6 , about 7.30 p.m., 3 young, one of which was not yet dry, and 2 eggs; July 7, 5.15 a.m., 3 young and 2 eggs; July 8, about 6 a.m., female banded, 5 young. On July 23 nest was empty, but contained feather-sheath particles, so the brood may have fledged.

Nest 3. Found June 28 , well sheltered by Cassiope, high on a slope with a southern exposure: 5 eggs. July 2 to 5 , nest visited daily, and female banded on July 5 . July 10 , 6 a.m., 4 young and one egg; July 16, 4 young and one egg; July 22, one well-developed dead nestling and one egg in the nest, 3 alert-looking nestlings huddled nearby. Nestlings banded; although at least 12 days old they could not fly, but we saw them flying two days later.

Nest 4. Found June 30 among Cassiope on a steep slope along the west side of the Sylvia Grinnell River, about half a mile from its mouth: 3 eggs. July 1, 3 eggs; July 15, 3 young; July 25, 3 young all dead and somewhat decomposed. The young probably died about July 18 or 19 .

Nest 5. Found July 1 among blooming Cassiope on a steep slope along the west side of the Sylvia Grinnell River in a sheltered spot with southern exposure: 3 eggs. July 2, 2 eggs only; July 15, nest empty, no feather-sheath particles.

Nest 6 . Found July 1 in moss on an almost perpendicular two-foot bank in a sheltered spot along the southwest edge of a rocky outcrop on Davidson Point: 6 eggs. July 2, 6 eggs; July 12, 6 young; July 17, nest found scattered, probably the work of a dog.

Nest 7. Found July 4 at the base of a mossy hummock about thirty yards east of the building in which we lived: 5 eggs. July 5 to 12, nest visited daily; incubating bird banded on July 5. July 11, 7 a.m., 4 young and one egg; July 16, 4 young and one egg; July 21, 4 well-developed dead nestlings and one egg, parent birds had left the vicinity.

Nest 8. Found July 5 in a sheltered mossy spot among large rocks: 5 eggs. July 6, incubating bird banded. July 7 to 16 , nest visited daily. July 8 , about noon, 5 eggs; July $9,2.30$ p.m., 3 small young and 2 eggs, one of the parents was seen to carry an egg-shell from the nest; July 10, 6.30 a.m., 4 young and one egg, at 4 p.m., 5 young; July 16, 5 sturdy young; July 21, 3 well-feathered young dead in nest and the parents had left. Two young may possibly have fledged.

Nest 9. Found July 6 among Cassiope on a high mossy slope with southern exposure about a mile and a half northeast of the airfield: 5 eggs. Nest not visited again.

Nest 10. Found July 7 among moss and Cassiope on a vertical bank about four feet above a narrow area of wet grassy tundra, half a mile east of the airfield: 5 eggs. July 22, 4 well-developed dead nestlings and one egg. The young must have died some days previously.

Nest 11. Found July 10 in a thick growth of Cassiope, twenty feet below the top of a steep, moss-covered rocky slope, about two miles east of the airfield: 5 small young. Nest not visited again. 
Nest 12. Found July 12 in flat grassy tundra about a quarter of a mile north of the airfield: 6 young, the smallest of which had hatched very recently. Young were of various sizes. July 15, 6 young; July 17, 6 young; July 21, 6 young all dead and somewhat decomposed in the nest.

Nest 13. Found in mid-July by a civilian employee at the airfield on a mossy hummock in marshy tundra near a rocky slope on Davidson Point: 5 eggs. July 30, nest found torn from its site; some feathers of fairly well developed young birds were among the remains.

Nest 14. Found July 18 among Cassiope in the middle of a wide expanse of grassy tundra, well away from rocks, not far from the mouth of the Jordan River: 5 fairly well developed young. Nest not visited again.

Table 1. Fourteen Baffin Island Water-Pipit nests

\begin{tabular}{|c|c|c|c|c|c|c|}
\hline Nest & $\begin{array}{l}\text { Contents } \\
\text { when } \\
\text { found }\end{array}$ & $\begin{array}{l}\text { Young } \\
\text { known to } \\
\text { have } \\
\text { hatched }\end{array}$ & $\begin{array}{c}\text { Eggs } \\
\text { known not } \\
\text { to have } \\
\text { hatched }\end{array}$ & $\begin{array}{c}\text { Young } \\
\text { found dead } \\
\text { in nest }\end{array}$ & $\begin{array}{l}\text { Young } \\
\text { known to } \\
\text { have } \\
\text { fledged }\end{array}$ & $\begin{array}{l}\text { Young } \\
\text { possibly } \\
\text { fledged }\end{array}$ \\
\hline 1 & 6 eggs & 5 & 1 & 0 & & 5 \\
\hline 2 & 5 eggs & 5 & 0 & 0 & & 5 \\
\hline 3 & 5 eggs & 4 & 1 & 1 & 3 & \\
\hline 4 & 3 eggs & 3 & 0 & 3 & & \\
\hline $5^{1}$ & 3 eggs & & 1 & & & \\
\hline $6^{2}$ & 6 eggs & 6 & 0 & & & \\
\hline 7 & 5 eggs & 4 & 1 & 4 & & \\
\hline 8 & 5 eggs & 5 & 0 & 3 & & 2 \\
\hline $9^{3}$ & 5 eggs & & & & & \\
\hline 10 & 5 eggs & 4 & 1 & 4 & & \\
\hline $11^{3}$ & 5 young & 5 & 0 & & & \\
\hline 12 & 6 young & 6 & 0 & 6 & & \\
\hline $13^{2}$ & $5 \mathrm{eggs}$ & 5 & 0 & & & \\
\hline $14^{3}$ & 5 young & 5 & 0 & & & \\
\hline
\end{tabular}

\section{Nest success and species survival}

Table 1 reveals an astonishing fact: not one nest of the fourteen did we know to have been 100 per cent successful in fledging, and only one (Nest 3) did we know to have been successful at all. In this nest five eggs were laid. Of the four young which hatched, three left the nest shortly before being able to fly, while one died about the time its siblings left the nest. Seven of the fourteen nests we know to have been 100 per cent unsuccessful. Of these at least two were destroyed by predators and five failed, probably because of bad weather.

On the basis of our observations, the pipit was the least successful in its nesting of all the birds of the Frobisher Bay area in the summer of 1953. As Table 1 shows, the principal losses were of well-developed nestlings, and this loss took place chiefly during the third week of July, when the weather was especially bad. We were away from the airfield, at the mouth of the Jordan River, from July 17 to 20 . The weather during most of that period was foul. When we returned, on July 21, we found three nestfuls of young pipits which 
had died while we were away. On July 22 and July 25 we found more nestfuls of young so badly decomposed we could not save them as skins, so the broods must have died some days before. The most lethal period probably was the wet, foggy, cold, and windy 48-hour period of July 18-19. The weather data for this period are given in Table 2 .

Table 2. Weather conditions at Frobisher airfield, $17-21$ July 1953

\begin{tabular}{|c|c|c|c|c|c|}
\hline Date & $\begin{array}{c}\text { Minimum } \\
\text { air }^{\circ} \\
\text { temp. }{ }^{\circ} \mathrm{F}\end{array}$ & $\begin{array}{c}\text { Maximum } \\
\quad \text { air } \\
\text { temp. }{ }^{\circ} \mathrm{F}\end{array}$ & $\underset{\text { wind }}{\operatorname{Minimum}}$ & $\underset{\text { wind }}{\text { Maximum }}$ & $\begin{array}{l}\text { Prevailing } \\
\text { wind }\end{array}$ \\
\hline July 17 & 37.4 & 53.1 & Calm & 16 m.p.h. (NW.) & 10 m.p.h. (NW.) \\
\hline July 18 & 36.2 & 41.6 & Calm & 30 m.p.h. (SE.) & 13 m.p.h. (S.-SE.) \\
\hline July 19 & 36.0 & 40.8 & 9 m.p.h. (S.-SE.) & 21 m.p.h. (S.-SE.) & 15 m.p.h. (S.-SE.) \\
\hline July 20 & 35.1 & 45.1 & Calm & 30 m.p.h. (S.-SE.) & 17 m.p.h. (S.-SE.) \\
\hline July 21 & 35.9 & 46.4 & 4 m.p.h. (W.-NW.) & 40 m.p.h. (NW.) & 17 m.p.h. (NW.) \\
\hline
\end{tabular}

This breeding record for fourteen pairs of pipits is appallingly poor, and the ultimate fate of any pipit population obliged to live under continuing conditions so unfavourable to reproduction is obvious. For a time in late July we thought that the whole pipit crop of our area had failed. However, from mid-July on we saw many young birds. On July 18, not far from the mouth of the Jordan River, we caught a strong-flying young bird with tail about one inch long. We let this bird go. On July 27 , along the west side of Tarr Inlet, we happened upon a brood not long out of the nest. On July 24 we saw a few scattered young birds in high country northeast of the airfield. A female (GMS 11789) collected that day had fully developed flight feathers and might well have been of an early June brood. From July 25 to August 10 we saw several young birds daily near the airfield. On August 1 we collected a juvenal male (GMS 11799) with flight feathers still slightly sheathed at the base. On August 10 we saw a stub-tailed bird not long out of the nest.

These late records for young birds, far from being proof of two broods, are nevertheless evidence that some eggs or nestlings survived the lethal midJuly weather. A question naturally arises concerning the nests found by us: were they the most findable, hence the most exposed and vulnerable to the weather? Does Table 1 present a distorted and misleading picture? We believe not. We believe that throughout the whole Frobisher Bay area nestlings which were well developed in mid-July perished between July 18-19. We further believe-and suggest that careful observations along this line be madethat the only young birds which died were almost ready to fledge, i.e., in need of much food; that younger birds, not in need of so much food, survived; and that pairs which lost well-developed nestlings made no attempt to nest again. Granting that a pair, having lost a brood on or about July 19, might attempt to re-nest, let us review the requirements: at least a day would be needed for nest-building, 3 or 4 days for egg-laying, 12 days for incubation, and 13-14 days for fledging (Johnson, 1933, pp. 114-5): a total of 30-31 days. Stubtailed young which we saw on August 10 were obviously not from a brood reared after July 19. We saw no stub-tailed young later than August 10. 
The fact that we examined so many dead nestlings continues to amaze us. Why were these not eaten by predators? Although we did not see a trace of a weasel (Mustela erminea) or fox (Alopex lagopus) near any of the pipit nests we were observing, lemmings (Lemmus trimucronatus and Dicrostony $x$ groenlandicus) were common. Yet not one of the dead pipit nestlings had been chewed at in the slightest.

\section{Description of specimens}

The following four adult Water-Pipits were collected near the airfield. They represent the well-known race Anthus spinoletta rubescens. We have not, however, had specimens of the races $A$. s. pacificus and $A$. s. monticola for comparison. Measurements are in millimetres.

$\begin{array}{clccccc}\text { GMS No. } & \text { Sex } & \text { Date } & \text { Wing } & \text { Tail } & \text { Culmen } & \text { Tarsus } \\ 11722 & \text { Male } & \text { June 24 } & 84.0 & 65.0 & 13.0 & 23.5 \\ 11723 & \text { Female } & \text { June 24 } & 82.5 & 66.0 & 12.5 & 22.5 \\ 11728 & \text { Male } & \text { June 26 } & 85.0 & 64.0 & 13.0 & 24.0 \\ 11733 & \text { Male } & \text { June 29 } & 84.0 & 65.0 & 13.5 & 23.0\end{array}$

Two of these specimens (female, 11723; male, 11733) are heavily streaked on the chest and sides, the other two are not. The heavily streaked male is unique in this series in having a complete, though narrow and not very noticeable, dark malar stripe. The heavily streaked female has a much interrupted malar stripe. The comparatively unstreaked specimens (11722, 11728) differ from the other two in being more vinaceous below (especially 11722 ) and in having a much reduced and interrupted malar stripe. The four specimens vary as regards the white in the tail. The outermost rectrices have about the same amount of white throughout the series, but the next pair are whitest in 11728 (male) and 11723 (female).

The two specimens with heavily streaked plumage may be in their first breeding plumage (see Ridgway, 1904, p. 13, footnote), but Dr. Kenneth C. Parkes, who at our request examined the extraordinarily fine series of adult Water-Pipits in the Carnegie Museum collection in Pittsburgh, believes that degree of streaking may not be an age phenomenon, but rather "some sort of incompletely developed sexual dimorphism".

Dr. Parkes's comments are so interesting that we quote at length from his letter of 24 February 1954: "I segregated out all of our presumably breeding pipits, and found that our series segregated roughly into three groups. The first consisted of those birds which varied from almost immaculate to those with a partial (broken) ring of spots across the chest. A fairly well-defined middle group has a very clear-cut and definite ring of spots across the chest, but little additional spotting. The third group has the most spotting, varying from the single ring supplemented by additional spots to those few extreme birds with heavy streaking ... Among the unstreaked birds there is little or no correlation between sex and amount of streaking .... On the other hand, the heavily streaked end . . . is dominated by females."

Dr. Parkes adds that "there is no indication whatsoever of any geographic correlation; each category contains birds from points as far apart as Labrador 


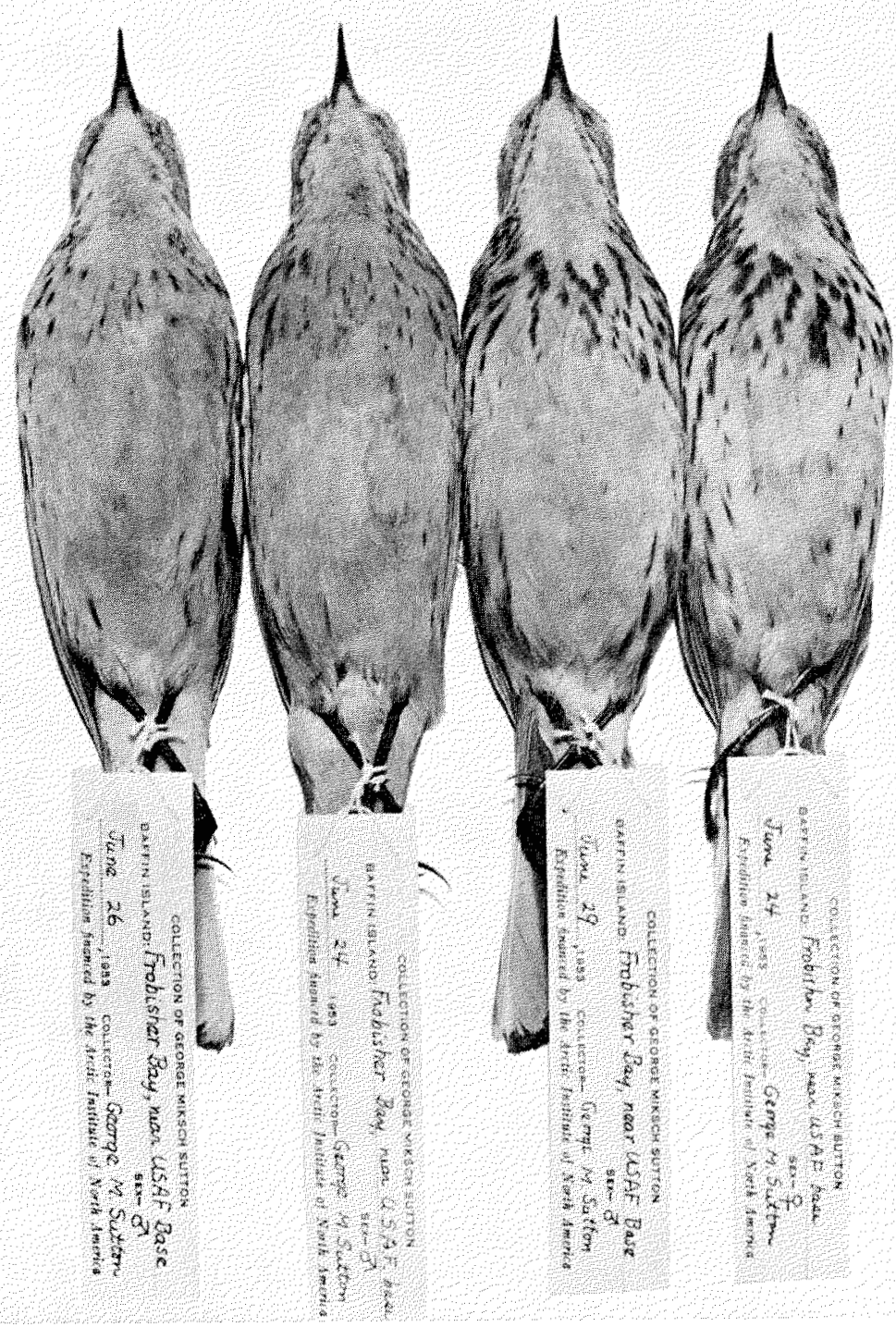

Fig. 3. Adult Water-Pipits in breeding plumage, collected near the head of Frobisher Bay in June 1953. The only female is at the right. This bird's matc is second from the left.

and the Mackenzie Delta". He further states that "on the average, the less heavily streaked birds have the best development of the bright pinkish-buff ground color".

Our two specimens in full juvenal plumage (male, GMS 11799; female, GMS 11789) are much alike, but the male is paler on the chin and throat, has a much more noticeable buffy white superciliary spot back of the eye, and has more white in the outer rectrices than the female. 
We find no sexual dimorphism in the four nestlings. In all the cheststreaking is dark and heavy and the rich buff of the belly is slightly tinged with pink. The natal down, which clings in profusion to the sides of the crown, middle of the hind neck, scapulars, and rump, is mouse gray.

This work was made possible by a grant from the Arctic Institute of North America. ${ }^{1}$ We also wish to thank Douglas Tesch, of the Meteorological Division of the Canadian Department of Transport, for concise weather data; V. C. Wynne-Edwards, of Aberdeen University, for help in the field; and Kenneth C. Parkes, of the Carnegie Museum in Pittsburgh, for his opinion on sequence of plumages and colour variation in Anthus spinoletta.

${ }^{1}$ With funds provided by the U.S. government.

\section{References}

Austin, Oliver Luther, Jr. 1932. 'The birds of Newfoundland Labrador'. Mem. Nuttall Ornith. Club, No. 7, 229 pp.

Bailey, Alfred M. 1948. 'Birds of arctic Alaska'. Colorado Mus. Nat. Hist. Pop. Ser. No. 8, 317 pp.

Bent, Arthur Cleveland. 1950. 'Life histories of North American wagtails, shrikes, vireos, and their allies'. U.S. Nat. Mus. Bull. No. 197, 411 pp.

Bray, Reynold. 1943. "Notes on the birds of Southampton Island, Baffin Island and Melville Peninsula". (With comments by T. H. Manning), $A u k$, Vol. 60, pp. 504-36.

Dalgety, C. T. 1936. "Notes on birds observed in Greenland and Baffin Land, JuneSeptember 1934". Ibis, Vol. 6, Thirteenth Ser. pp. 580-91.

Johnson, Hazel S. 1933. "Notes on the family life of a pair of American Pipits". Wilson Bull. Vol. 45, pp. 114-7.

Kumlien, Ludwig. 1879. "Birds" in "Contributions to the natural history of arctic America made in connection with the Howgate Polar expedition, 1877-78'. U.S. Nat. Mus. Bull. No. 15, pp. 69-105.

Pickwell, Gayle. 1947. "The American Pipit in its arctic-alpine home". Auk, Vol. 64, pp. $1-14$.

Ridgway, Robert. 1904. 'The birds of North and Middle America'. U.S. Nat. Mus. Bull. No. 50, Pt. 3, 801 pp.

Shortt, T. M. and H. S. Peters. 1942. "Some recent bird records from Canada's Eastern Arctic". Can. J. Res. Sect. D, Vol. 20, pp. 338-48.

Soper, J. Dewey. 1928. 'A faunal investigation of southern Baffin Island'. Nat. Mus. Can. Bull. No. 53, pp. 76-116 (Birds).

1946. "Ornithological results of the Baffin Island expeditions of 19281929 and 1930-1931, together with more recent records". Auk, Vol. 63, pp. 1-24, 223-39, and $418-27$.

Sutton, George Miksch. 1932. "The birds" in "The exploration of Southampton Island, Hudson Bay'. Mem. Carnegie Mus. Vol. 12, Pt. 2, Sect. 2, pp. 1-275.

Taverner, P. A. 1935. "Birds of the Eastern Arctic" in 'Canada's Eastern Arctic'. Ottawa: Dept. of the Interior, pp. 113-28.

Wynne-Edwards, V. C. 1952. "Zoology of the Baird expedition (1950). I. The birds observed in central and south-east Baffin Island". Auk, Vol. 69, pp. 353-91. 